\title{
Role of Tourism in Global Economic Integration
}

\author{
Ola Bazaza, Pharm., Pharm. MBA \\ Beirut, Lebanon- Beirut Arab University, Faculty of Business Administration, \\ doctorate in business administration \\ Oi.bazaza@hotmail.com
}

\begin{abstract}
Tourism is considered as one of the major components in the economy, since it increases job creation, enhance the social level, decrease poverty and increases the opportunities for entrepreneurs to prove their skills especially women (Caroline Ashley). Having an integrated economy where borders are removed, tourism is more facilitated and those countries would benefit economically, where the number of tourists increase. As we can see that the EU region is considered the first destination for tourism, in addition to the nature landscape, having an integrated economy, sharing a single market played a major role in increasing this tourism trips, especially that most tourists are from Europe. Tourism is very important in Lebanon and should be developed, through building a good image, create linkages between different sectors, taking into consideration that we can get short term or long term results accordingly.
\end{abstract}

Keywords. Tourism, Global economic integration, Lebanon, European union

\section{Introduction}

Tourism

Many countries consider tourism a crucial economic component, due its positive effects on economy. Tourism increases job offers and availability directly in hotels, restaurants, stores and transportation, and indirectly through other products and services that support tourism (agriculture, industry, ecology, etc.). This creation for new opportunities would increase the income for the workforce and which would increase the standard of living for local population. Tourist destination would bring good revenues paid as taxes and fees from the companies working in this field. In addition, to the increase in local products exportation, it is estimated to have $15-20 \%$ of tourists expenditure spent on gifts, clothes and souvenirs. Tourism increase depending on the degree of infrastructure development, private investors, the economic development level, and destination marketing ability (Bunghez, 2016 ). There are several types of tourism, affecting the global economy accordingly, for example business tourism, medical tourism and pilgrimage. These different types activate different sectors and offers different job opportunities. 


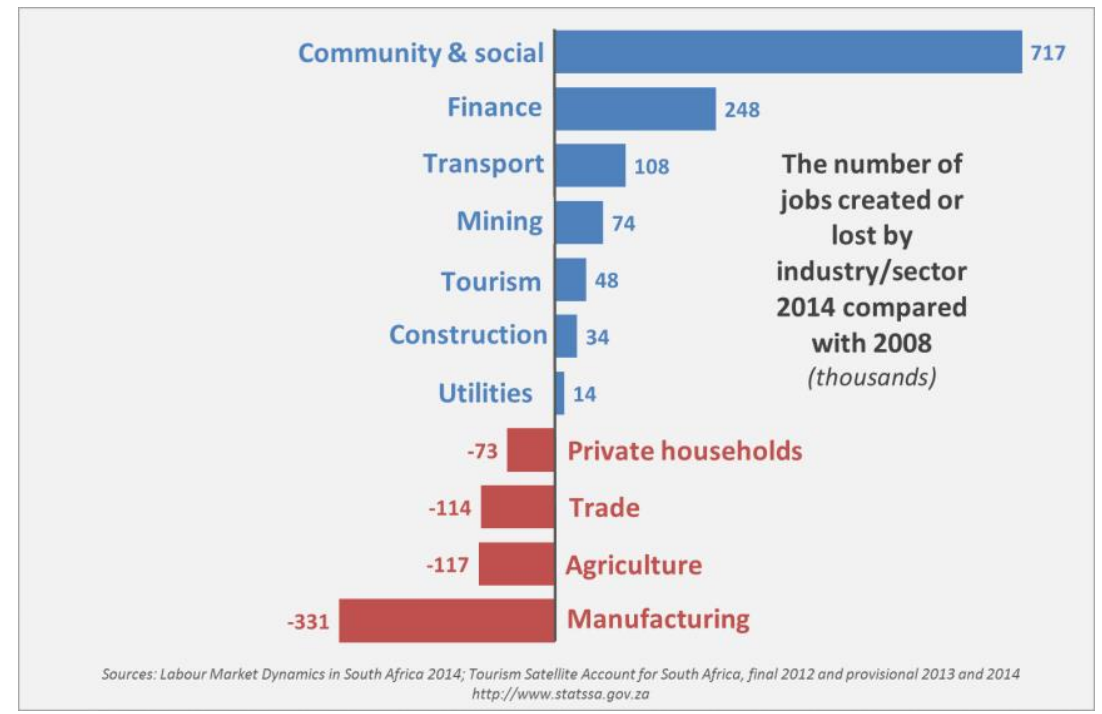

Figure 1: labor market Dynamics in South Africa

Taking South Africa as an example, we can see in figure 1, tourism has exceeded agriculture, trade and construction sectors in creating different and additional jobs in 2014 compared with 2008, so that tourism showed improvement and growth and this would be reflected on the national economy (Statistics South Africa, 2016).

Getting more into details, tourism offers not only a high number of new job opportunities yet it offers different and varied types of jobs. As we can see in figure 2, tourism participates in different fields' enhancement, mostly food services and drinking places, clothing stores, accommodation services etc... (Patterns, 2013)

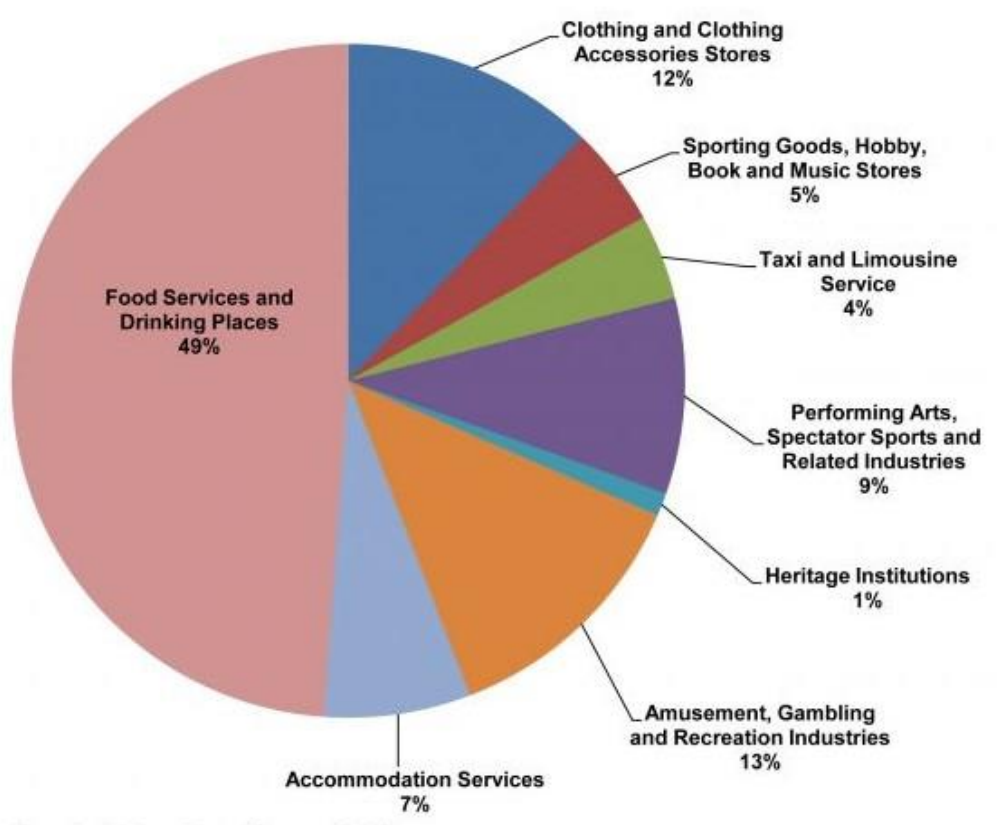

Source: Statistics Canada, Labour Force Survey (2013) Note: Employment is by place of residence

Figure 2: total employment in tourism 


\section{Integrated economy:}

To ensure the economic development in any country, tariff and non-tariff barriers to the free flow of goods or services and factors of production among each other's should be reduced or eliminated, in addition to the agreements between countries to coordinate their trade, fiscal, and monetary policies should be taken into consideration, this is what we call economic integration. Economic integration has different stages starting from free trade area, in which countries agree on eliminating tariffs on most goods traded between them. The next stage is customs union, in which tariffs are unified on the external border of the union. Stage three is establishing common market and it is characterized by the unification of economic policies, the goal is to facilitate the movement of capital, labor, goods, and services between them easily forming a single market with many advantages such as, allocating resources efficiently increasing productivity and competitiveness which makes the formation of monopolies more difficult, where efficient firms can benefit form economies of scale and customers can get their products with lower prices with variety of choices and new innovative ones. The fourth stage is economic and monetary union, where a group of countries share the same currency. Finally, the last stage is complete economic integration, where the integrated units have no control over economic policies with full monetary union (Yuri Kirillov, 2015 ).

Globalization has affected every field of social life. Global economy was affected with globalization in different ways such as, liberalization of international trade, competition, free movement of capital and work force, investments, removing any barrier for capital, goods, financial and investment flows. Tourism is considered one of the most important economic activity in this process, so that the development of tourism is seen in every dimension in globalization; economic, social, cultural and even political. The effect of globalization on tourism is characterized by the progress and transfer of technology, open borders, travelers' transportation which became cheaper (air travel cost is decreasing) due to the reduction in the intermediaries importance) and communication which became fast and easier. This decrease in the cost would increase the number of people that can afford enjoying tourism inside and outside borders. Tourism results in an economic development due to the fact that tourism connect the sales of services and goods, every sale have a significant effect on small businesses. This influence of globalization on tourism is reflected by the fact that the number of tourists is increasing on yearly basis. (Slobodan Cerovic, 2015).

\section{Effect of Tourism on Economic Growth}

The total impact of tourism on economy is impressive. In 2017, tourism represented a total on $10.4 \%$ from the global GDP which is approximately equal to 8.2 trillion dollars and offered 313 million job opportunities and it represented $4.5 \%$ of total investment. It is expected that in 2022 it will exceed these numbers (Scowsill, MARCH 2018). It is considered the fourth export industry after fuel, chemicals and food. (F. Balli, 2015). The level of the effect of tourism on economic growth varies according to each country, such that the relation between tourism and economic growth is bidirectional causality, examples; Taiwan and Korea whereas this relation differs in Turkey since it is unidirectional causality (L. Gunduz, 2005).

This economic stimulation is due to first, the contribution of foreign exchange reserve supporting the production process through new technologies. Second, tourism increases the investment in infrastructure and human capital (A. Lemmetyinen, 2009). Third, industrial development is stimulated by tourism due to the spillover effect and consequently creates jobs and increases earnings, finally creating positive economic externalities.

Tourism reduces the levels of poverty, through three different ways, first through increasing wages and outcomes giving the chance for unskilled or semi-skilled labor to work 
(such as taxi drivers, guides..) in urban or rural areas accordingly examples Cappadocia and Istanbul and thus creating opportunities and chances for poor people to work, through creating new fields such as handcrafts, cultural tourism. (Caroline Ashley). Tourism encourage entrepreneurs to prove their skills as they would have a wider market, and higher opportunity to succeed. Second, to complete the value chain of tourism, in order to meet the needs of tourists and gives distinctive services to maintain the level of tourism in a specific country, other sectors should be dedicated to reach this desirable outcomes, through offering the best quality of food and beverages, furniture, construction, and transportation. Up to half of total poor people in Namibia and Luang Prabang in Laos (Southeast Asia) works differently in tourism supply chain, distributed among different fields such as accommodation and transportation, bars and restaurants, handicrafts, food production, infrastructure and waste disposable, all these roles are supportive to a successful tourism (Richard Tapper, 2004)

Finally, the dynamic effects caused by tourism; and it is characterized by small enterprises development, increase in the demand on hand crafts produced by women in the informal sector and consequently the purchasing power will increase (Caroline Ashley). The level of impact differs according to the host company, supply side factors, government policies, the type of tourism (medical, business...), and tourism companies' business practice.

As we can see in figure 1, the level of job opportunities offered because of tourism increased between 2008 and 2018 and it is expected to reach $11.6 \%$ of total employment by the end of 2028.

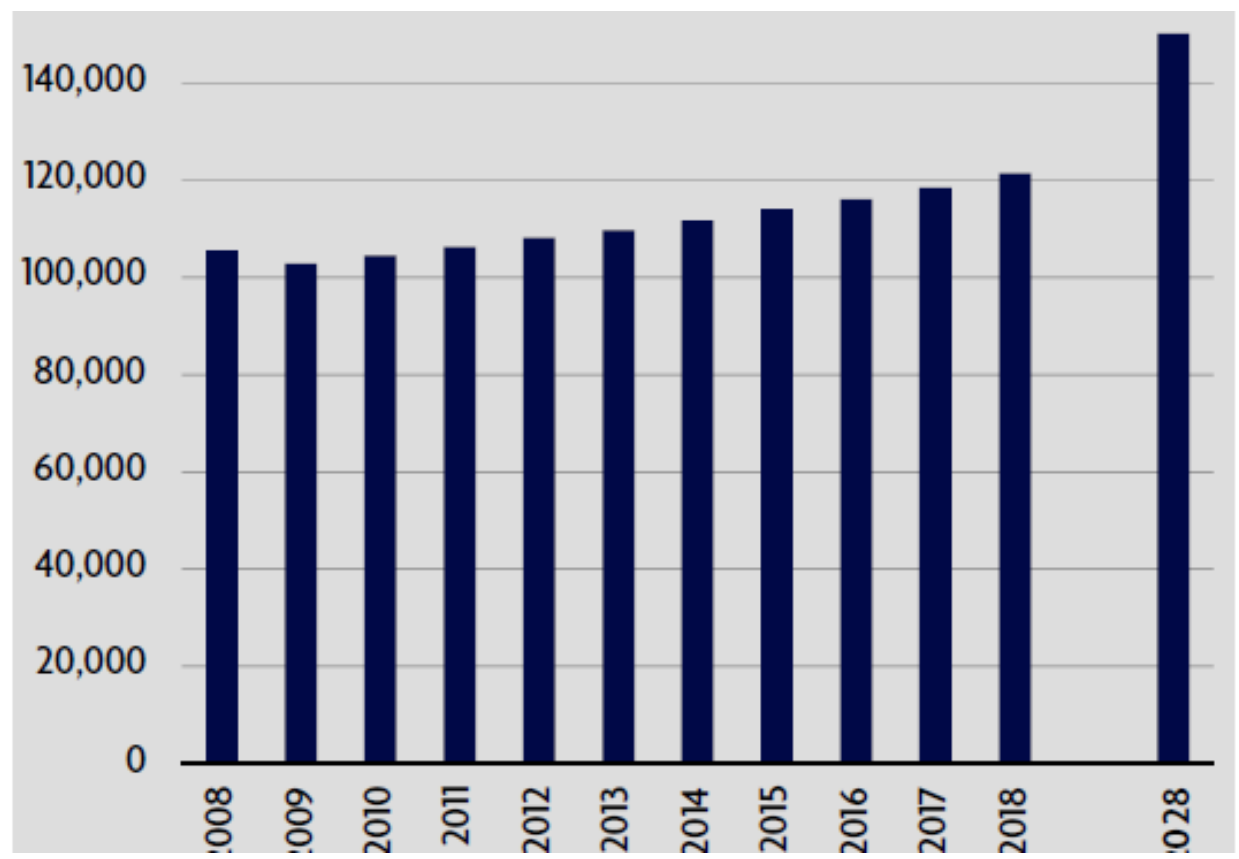

Figure 3: Direct contribution of tourism to employment 


\section{Tourism in European Union}

Economic globalization main value is to release business and allow national economic competitiveness to reach integration into global markets. Societies that adapted these changes have benefited from this process and worked passively through entering regional economic integration as they protected their economy against global competition through relying on different economic potentials and gaining various resources from different economic regional integrations. This integration can help developing countries to enter the global field. In this case investments in the region would increase, enhancing the economic growth and development through increased mutual capital volume. The first step in moving towards globalization is through regional integrations in which countries can overcome world's financial crisis.

The main advantage in this integration is to remove barriers and obstacles, and facilitate business formation and economic enhancement through reduced taxes, simplified tourism (as discussed before how tourism could support national economy, removing barriers would enhance its role). The goal of this integration is to increase the global production and specifically the specialized domestic production and obtain exchange revenues, this would decrease the regional expenses, conserve domestic resources, distribute optimum outcomes, enhance efficient production and business, encourage foreign investments and exploit comparative advantages (Mehdi Hosseiny Naveh, 2012). Economic integration can be applied after economic, political and institutional cooperation. Economic integration has two levels, first include; economic, political, historical, cultural and social, whereas the second levels has economic, financial, monetary etc. The European Union was successful because it combined the cooperation and the integration from which it was capable of developing a rigorous but flexible approach. The process of any economic integration have the same steps but different starting points; such that the integration between industrialized countries has a developed frameworks but the integration between developing countries should ensure those (Koné, 2012).

\section{European Union}

The most famous union that has applied economic integration is the European Union (EU). EU began with a cooperation in trade and economy, and it was called European community in 1958, and more countries started to join this union and in 1993 the community became European Union with 28 European countries. The main goals for this union are; ensure development based on economic growth, competitive markets, social progress, environmental protection, technological progress, and establish economic and monetary union sharing the same currency "euro".

The impact of the EU was reflected through achieving a peaceful environment for more than half a century, it raised the level of living standards. People can travel throughout most of continent without borders. They share a single market so that people, goods, services, and money move freely among different countries in the EU, ending up to become the largest trade bloc and the biggest exporter (www.europa.eu.com, n.d.).

Europe is number one tourist destination with a $50 \%$ of the world's tourist arrival and this high tourism percentage helped Europe to have economic growth. As we can see in figure 2, the increased levels of EU tourism reflects on increased levels of income which will lead to economic growth (European Union Tourism Trends, 2018). 


\section{(1i) TECHNIUM}

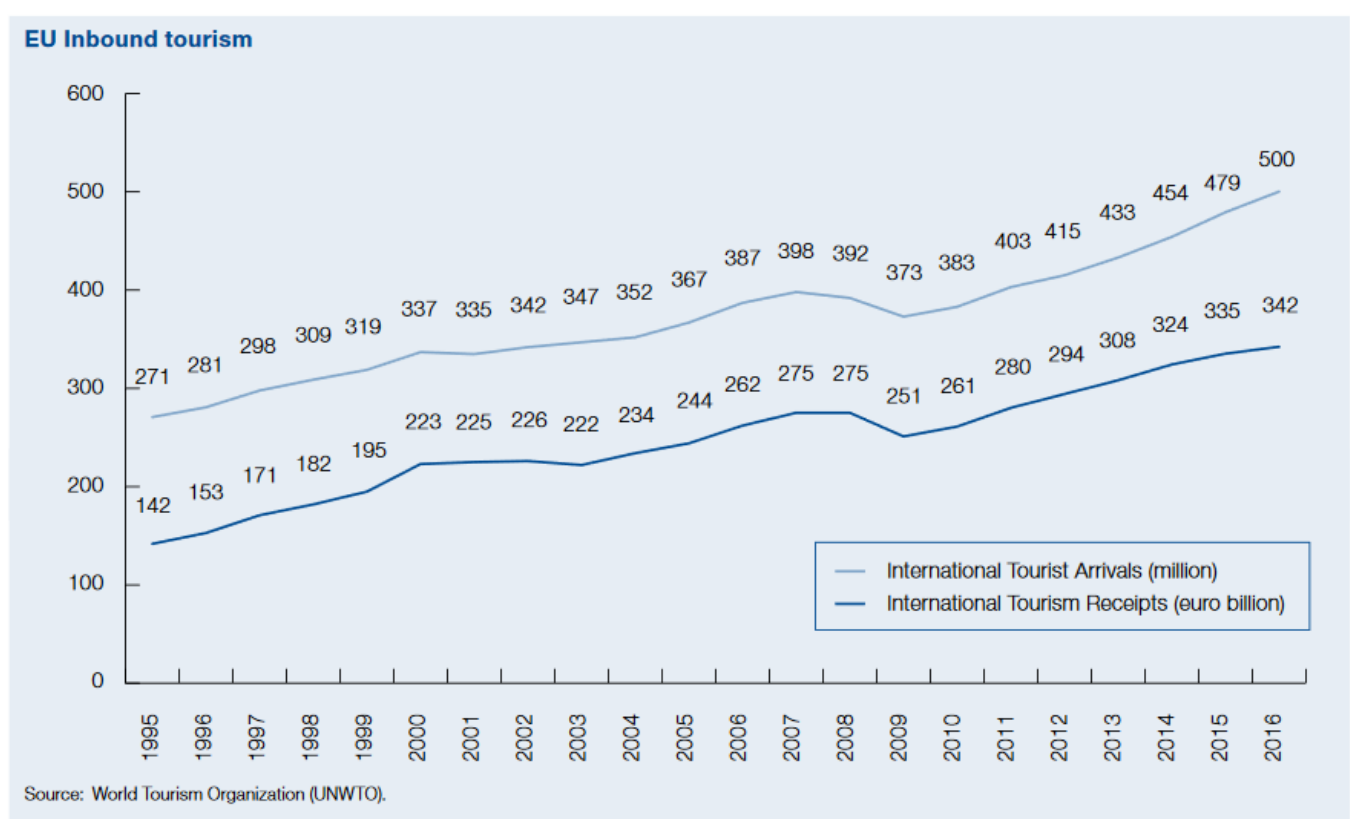

Figure 4: level of EU tourism and the level related to the international tourism receipts level

In $2015,61 \%$ of EU residents had one or more tourism trips, to have a sum of 1.2 billion trips spending 6 billion nights where $65 \%$ of these trips are within Europe. The average number of trips per Europe residents is 4 per year (European Union Tourism Trends, 2018). According to UNWTO tourism is expected to increase by $2 \%$ till 2020 and by $1.5 \%$ till 2030 . Tourism contributes directly 5\% of total EU GDP, and if we add the other linked industries (such as; distribution, construction, and cultural industries) the percentage will increase to $10 \%$ of EU GDP, and it is considered the third largest socio-economic sector in EU. This would show how to tourism can affect the economy through increasing employment opportunities, through establishing touristic industries. It is considered a stable sector and it is considered the least affected industry in economic difficulties (European Union Tourism Trends, 2018).

\section{Tourism Effect on the Lebanese Economy}

Lebanon's travel and tourism sector plays a vital role in the Lebanese economy, Lebanon has varied landscape, mild climate, and it has been considered a touristic hub for Arab and international visitors. The entertainment activities and the multilingual workforce has supported and helped this sector to boost and facilitates its growth. According to the world travel and tourism council, tourism contributes $6.8 \%$ of total GDP in Lebanon (Lebanon ranks in the $10^{\text {th }}$ position), and travel and tourism direct contribution to employment is $4.1 \%$ (bankmed).

Tourism in Lebanon is based on urban areas, where most entertainment activities are localized such as, night clubs, restaurants, and beach resorts. Recently nature tourism is increasing, but more developed infrastructure is needed. (Lebanon State of the environment report). 


\begin{tabular}{|l|r|r|r|r|r|r|}
\hline & 2009 & 2010 & 2011 & 2012 & 2012 & 2013 \\
\hline $\begin{array}{l}\text { direct contribution to } \\
\text { GDP }\end{array}$ & 3.6 & 17.3 & -17 & -5.3 & -7.5 & 7.7 \\
\hline $\begin{array}{l}\text { total contribution to } \\
\text { GDP }\end{array}$ & 6.6 & 22 & -15.1 & -3.7 & -6 & 6.9 \\
\hline
\end{tabular}

Table 1: Annual change of direct and total contribution of travel and tourism to GDP, 2009$2014(\%)$

Getting back to the history of tourism in Lebanon we can see that the percentage of tourism contributing to the GDP is high and it affect the Lebanese economy (refer to table 1) (Chlouk, November 2016).

\section{Marketing and positioning Lebanon tourism}

Lebanon's image around the world should be promoted in a different way to attract tourists. It is essential due to the conflicts Lebanon has passed through starting with civil then regional and internal conflicts. This stable situation should be reflected so that Lebanon is as safe as most countries around the globe. This marketing campaign is essential to rescue the sector and enhance the Lebanese economy. As we should take into consideration developing the rural tourism and supporting it with needed infrastructure to promote their touristic places in this case tourists would prolong their stay in Lebanon. As we should promote medical, gastronomy and wine tourism (Chlouk, November 2016).

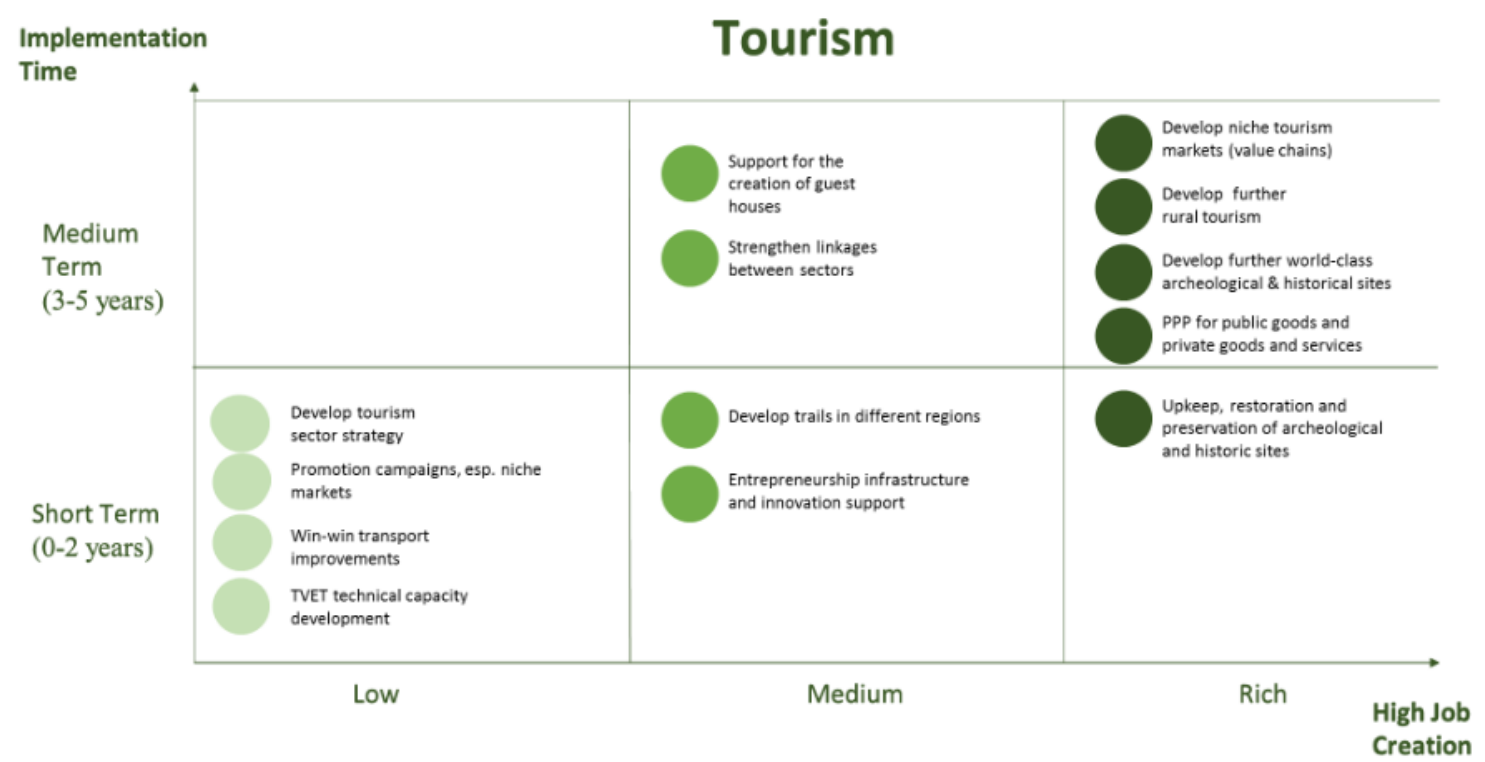

Figure 5: List of opportunities in the tourism sector by implementation time and potential for job creation

Focusing on tourism development ends up with economic growth as we see in figure 3 the effect of tourism on job creation varies from low to high and within different time ranges. It is never too late as we can get early results and grow with time. First, develop a tourism sector strategy, such as marketing, promoting the touristic image of Lebanon. Find a niche market that 
differentiate Lebanon what products are distinguished example olive soap production these two forward steps although they create jobs for a small number, yet they can support the Lebanese economy in the short term and may build for future further improvement. Second, any innovative support and entrepreneur infrastructure that may develop trails in different regions would also give results rapidly but with higher level of job creation. It is also important to create linkage between different sectors creatively example, we can combine the Lebanese tourism sector with agriculture, we have differentiated olive oil, citrus fruits, and apples... when tourists live the experience of the Lebanese differentiated products they would ask for it and with time our products would be exported to other countries this step has a medium term effect but with higher level of job creation. After establishing the previous steps, it would be easier to proceed and promote the tourism in the rural areas, maintain the historical sites and highlight the importance of our history and with these final steps highest levels of job creation can be accomplished, the purchasing power of the citizens would increase, and as we discussed before the tourism sector is very important in Lebanon and developing this sector would increase the GDP and consequently developing the Lebanese economy.

\section{Conclusion}

Finally, we can say that tourism is one of the major components of the economy. Focusing on tourism improvement would be a solution for countries that are suffering economic problems where it increases job opportunities, encourage entrepreneurial activities, women handicrafts... Economic integration enhance tourism within countries and it would lead to a more stable economy through sharing resources, single market, and currency. Lebanon economy depended on tourism for a long period of time, but due to internal conflicts the Lebanese image is in a need for a better marketing campaigns to be reflected in the right way to other countries. Encouraging the Lebanese tourism is a must and it may help in the economic growth.

\section{References}

[1] (n.d.). Retrieved from www.europa.eu.com: https://europa.eu/european-union/abouteu/eu-in-brief en\#from-economic-to-political-union

[2] Lemmetyinen, F. G. (2009). The key capabilities required for managing tourism business networks. 31-40.

[3] Bankmed. (n.d.). analysis of Lebanon's travel andtourism sector. Beirut: Bankmed Market \& Economic Research Division.

[4] Bunghez, C. L. (29 January 2016 ). The Importance of Tourism to a Destination's Economy. Journal of Eastern Europe Research in Bus.

[5] Caroline Ashley, P. d. (n.d.). The Riole of the tourism sector in expanding economic opportunity .

[6] Chlouk, D. G. (November 2016). Economic Opportunities and Job Creation: Tourism sector.

[7] (2018). European Union Tourism Trends. UNWTO.

[8] F. Balli, J. C. (2015). Inter-regional spillover effects in New Zealand international tourism demand. 262-278.

[9] Koné, S. (2012). Is Economic Integration Between Developing Countries a Singular Process? Journal of Economic Integration.

[10] L. Gunduz, A. H.-J. (2005). Is the tourism-led growth hypothesis valid for Turkey? 499-504.

[11] (n.d.). Lebanon State of the environment report. 
[12] Mehdi Hosseiny Naveh, T. T. (2012). Regional Economic Integration and its Effects on Economic Growth and Economic Welfare. World Applied Sciences Journal.

[13] patterns, C. b. (2013, December). Labour force survey 2013.

[14] Richard Tapper, X. F. (2004). Tourism Supply Chain.

[15] Scowsill, D. (MARCH 2018). The economic impact of travel \& tourism.

[16] Slobodan Cerovic, P. V. (January 2015). The influence of globalization on tourism and impact of tourism on other activities with the emphasis on green field investments in tourism.

[17] The World Travel and Tourism Council . (2011).

[18] Tourism Satellite Account For South Africa Final 2012 and provision 2013 and 2014. (2014).

[19] Yuri Kirillov, E. P. (Feb 11, 2015 ). Modern trends in international economic integration development . 